\title{
剣状突起下アプローチによる胸骨吊り上げ胸腔鏡下手術により 摘出した胸腺囊胞の一例
}

上林 孝豊, 大野 暢宏, 寺田 泰二

\begin{abstract}
要
旨

囊胞性病変を含志前中縦隔の良性腫瘍の切除方法は，開胸術か肋間からのアプローチによる胸腔鏡下手術で行われ ることが一般的である。今回我々は，剣状突起下アプローチにて胸骨吊り上げを行い，フレキシブルスコープを用い て胸腺囊胞を摘出したので報告する。症例は80歳男性。乾性咳嗽を主訴に当科を受診。胸部造影 CT, 胸部 MRI て前 縱隔左側に $44 \times 42 \times 38 \mathrm{~mm}$ 大の薄壁単胞性の囊胞性病変を認めた。胸腺囊胞を疑い, 剣状突起下アプローチによる胸 骨吊り上げ胸腔鏡下手術により囊腫を摘出した。病理組織学的に胸腺囊胞の診断を得た。前中縦隔の囊腫性病変の摘 出に対して本アプローチは有用であると考える。
\end{abstract}

索引用語：胸腺囊胞, 剣状突起下アプローチ, 胸骨吊り上げ法, 胸腔鏡下手術, フレキシブルスコープ thymic cyst, subxiphoid approach, sternum lifting method, thoracoscopic surgery, flexible fiber scope

はじめに

今回われわれは前縦隔左側に存在する $44 \times 42 \times$ $38 \mathrm{~mm}$ 大の薄壁単胞性の囊胞性病変を剣状突起下アプ ローチにて胸骨吊り上げを行い，フレキシブルスコー プを用いて摘出し, 病理組織学的に胸腺囊胞の診断を 得たので報告する。

\section{症例}

症 例: 80歳, 男性.

主 訴：乾性咳嗽。

既往歴：狭心症，パーキンソン病.

家族歴：特記すべきことなし.

現病歴：当院神経内科にてパーキンソン病の治療を 受けていたが，2003年12月初旬より乾性咳嗽を生じる ようになり，同年12月 8 日当科を紹介され受診。胸部 単純写真及び胸部 CTにて左肺門に突出する長径 $45 \mathrm{~mm}$ の腫瘤を認め (Fig. 1，2），2004年 2 月12日手術

市立長浜病院 呼吸器外科

原稿受付 2004年 4 月28日

原稿採択 2004年 6 月21日
加療目的にて入院となった。

入院時現症：身長 $165 \mathrm{~cm}$, 体重 $49 \mathrm{~kg}$, 血圧136/74 $\mathrm{mmHg}$, 脈拍 $72 /$ 分，心，肺音に異常なし，腋窩，鼠 径および頚部にリンパ節を触知せず。 performance

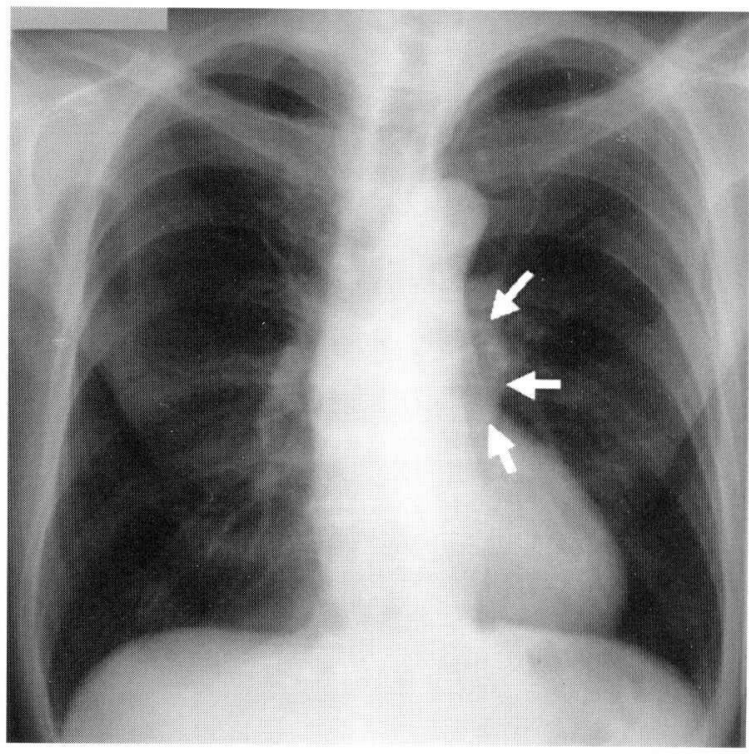

Fig. 1 Chest X-ray shows a rounded mass $45 \mathrm{~mm}$ in diameter protruding into the left hilar region. 

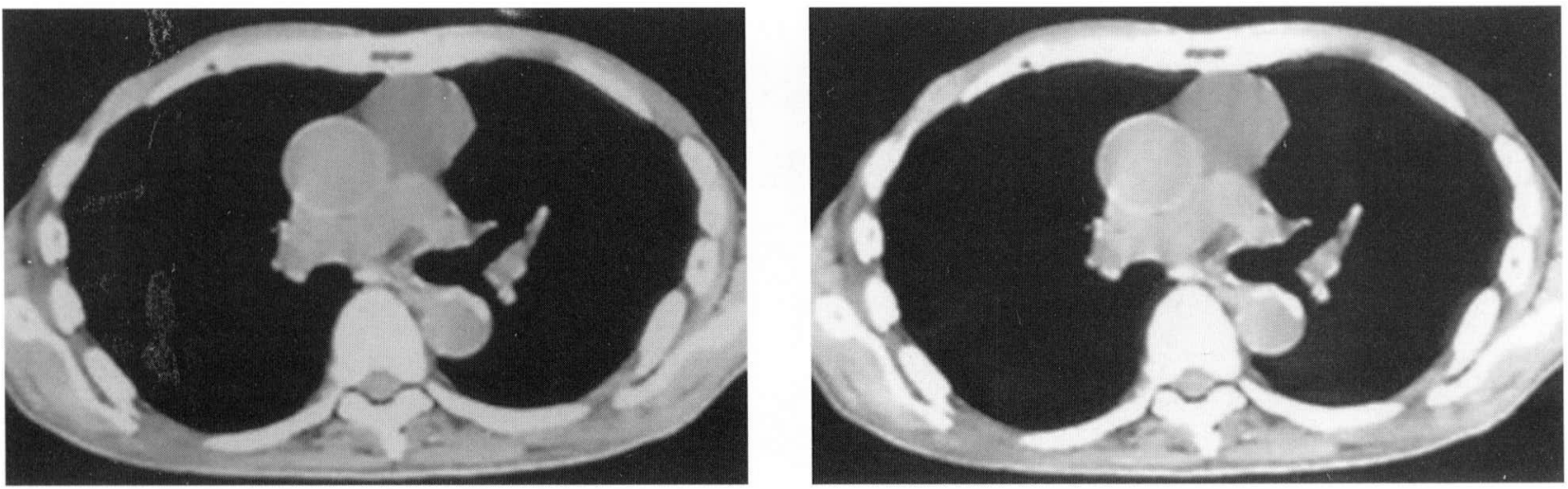

Fig. 2 Chest CT (right) demonstrates a rounded mass $(42 \times 38 \mathrm{~mm})$ on the left side of the anterior mediastinum. Contrast-enhanced chest CT (left) demonstrates a rounded and unilocular cystic mass with a thin capsule $(42 \times 38 \mathrm{~mm})$ on the left side of anterior mediastinum. The cystic structure had a homogenous internal density equivalent to that of water and it was not enhanced by contrast medium.
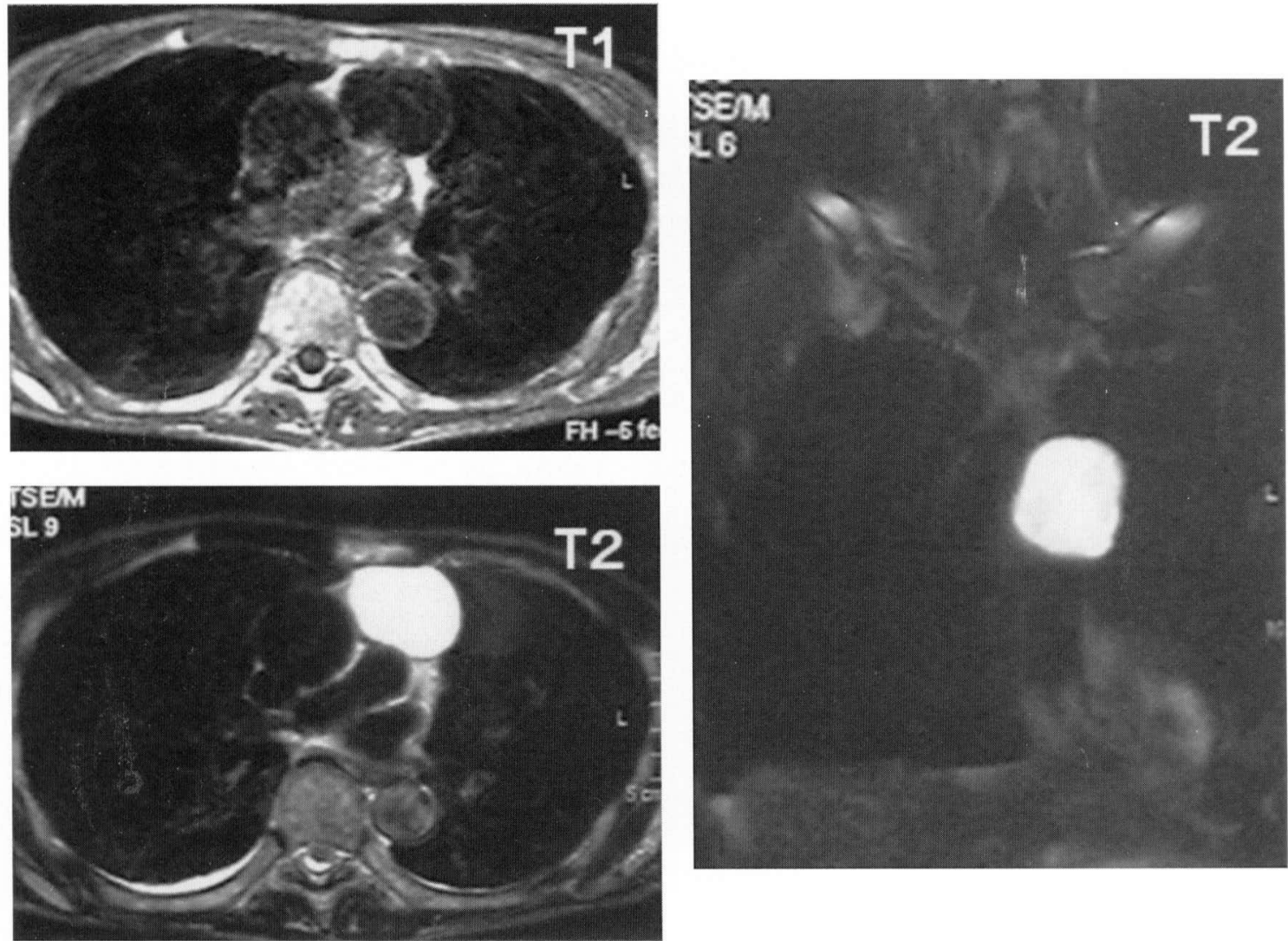

Fig. 3 Chest MRI revealed a mass with homogenous high signal intensity on a T2- weighted image.

statusは 2 であった.

検査所見：一般血液生化学検査では軽度の貧血を認 める以外は異常なし，血液ガス分析，呼吸機能検査， 心電図に異常を認めなかった。 CEA，CYFRA，可溶性 IL-2 レセプター抗体, 抗アセチルコリンレセプター抗 体はいずれも正常範囲内であった。
入院後, 胸部造影 $\mathrm{CT}$ と胸部 MRI を施行した。胸部 造影 CT (Fig. 2) では内部は造影されず均一な水吸収 值を示し, 胸部 MRI（Fig. 3) では T1 強調像（TR/TE 320/4.6）で低信号，T2 強調像（TR/TE 1650/90）で 均一な高信号を示し, 同病変は薄壁単胞性の囊胞性病 変であることが判明した。胸腺囊胞を疑い，2月17日 

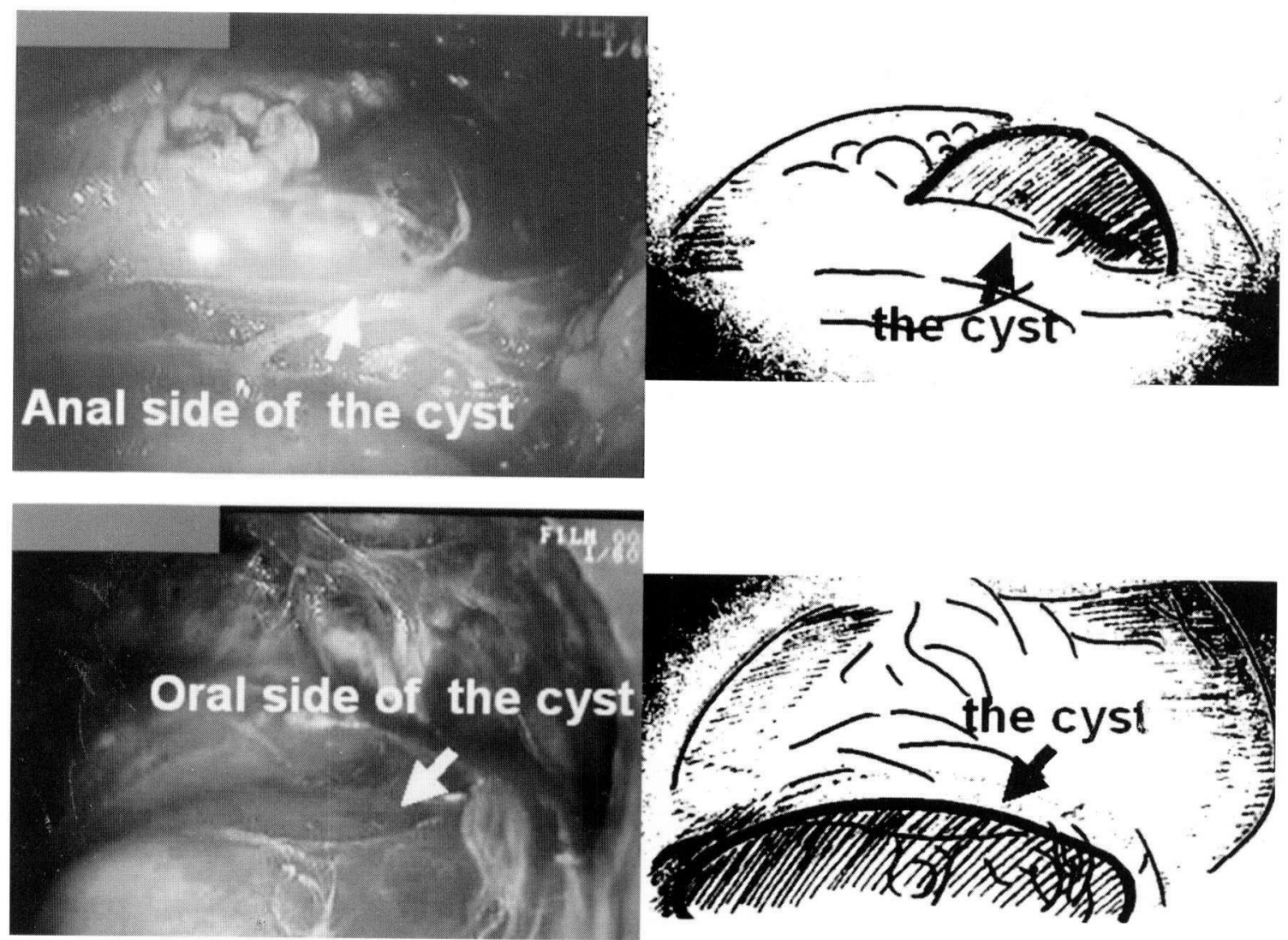

Fig. 4 The thoracoscopic view shows the pale and smooth-faced cystic mass buried in the fatty tissue around the thymus on the anal side of the AP window.

剣状突起下アプローチにて胸骨吊り上げを行い，フレ キシブルスコープを用いて胸腔鏡下囊胞摘出術を施行 した。

手術所見: 剣状突起を中心とする上下約 $6 \mathrm{~cm}$ の皮膚 切開ののち剣状突起の 1 部を切除した。剣状突起部の 皮切の左側に小切開を加え $11.5 \mathrm{~mm} の$ ポートを挿入し カメラポートとした，カメラにはフレキシブルタイプ のビデオスコープ(フジノン東芝ESシステム社, EL2TF410）を使用した。 剣状突起部の切開創に小開胸器 を装着し，鏡視下にツッペルにて胸骨裏面を剥離した。 途中, 剣状突起に筋鈎を掛け, これを劧引器 (MERA 泉工医科工業株式会社，抗研式肩甲骨保持率引鉤）に 装着することにより胸骨の挙上を保持した。さらに頭 側に剝離を進め左腕頭静脈を確認した。囊胞は AP window のやや尾側の胸腺周同脂肪織内に埋もれるよ うに存在し (Fig. 4)。これを摘出した (Fig. 5). なお 明らかな囊胞と心膜腔との交通は認めなかった。縦隔 内の出血の有無を確認したのち, カメラポート部を利 用し前縦隔に $24 \mathrm{Fr}$ ドレーンを 1 本挿入し手術を終了

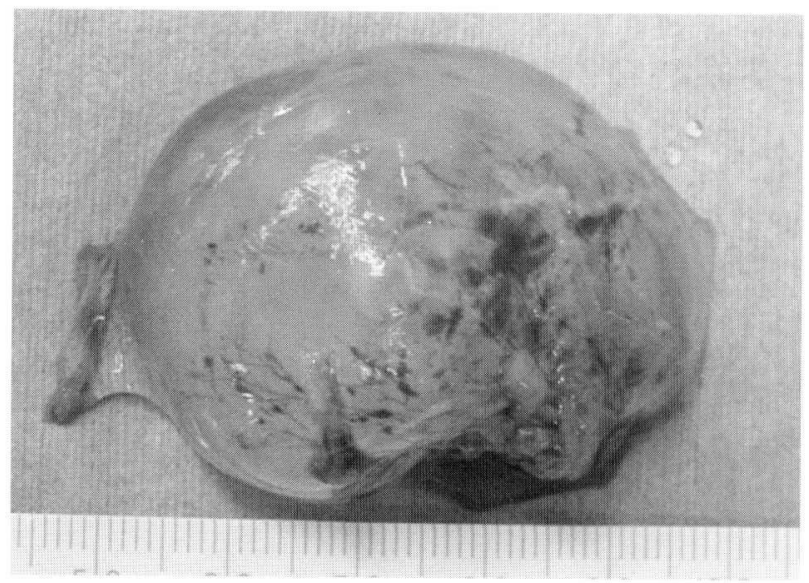

Fig. 5 Macroscopic findings show the thin, translucent-walled cyst containing a clear serous fluid.

\section{した。手術時間 116 分, 出血量 $70 \mathrm{~g}$ であった。}

病理組織学的所見 (Fig. 6) : 囊胞壁の内側面は一層 に並んだ立方上皮あるいは扁平上皮細胞からなり，囊 胞壁の一部には結合組織以外に正常な胸腺組織を認め, 胸腺囊胞の診断を得た。 


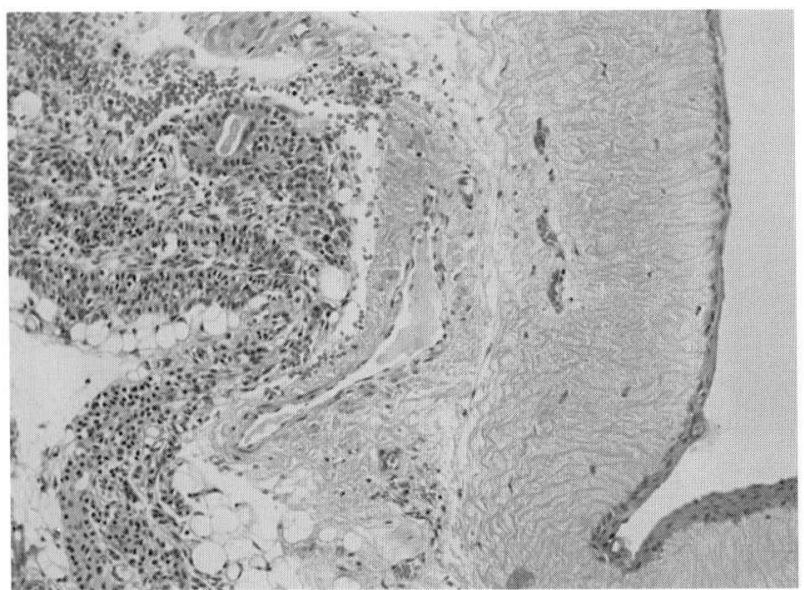

Fig. 6 Histological examination revealed that the thin cyst wall was lined by cuboidal and squamous cells and consisted of loose fibrous tissue and normal thymus tissue. (H.E. stain $\times 100$ ). These findings were compatible with those of a thymic cyst.

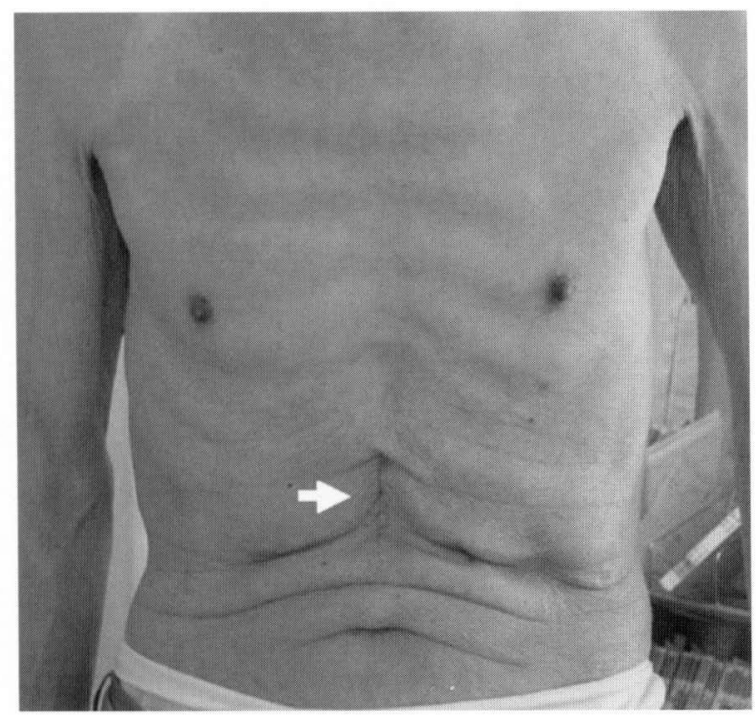

Fig. 7 Photograph of patient 2 weeks after discharge.

術後経過は良好で術翌日にドレーンを抜去し, 術後 4 日目に退院となった。なお術後鎮痛剂の使用はド レーン留置期間のみであった（Fig. 7).

\section{考察}

胁間アプローチによる胸腔鏡下手術は縦隔腫瘍に対 して有効な方法として近年，広く行われるようになっ てきた。しかし囊胞性腫瘤の場合, 容易に壁が破れ不 完全切除になりやすいこと, 大きな病変の際には視野 の邪魔になり完全切除が困難であることなどの問題点
が指摘されている11. 今回われわれは, 術前, 胸腺囊 胞と考えられる前縦隔の囊胞性腫瘤に対して, 胸腺腫 や重症筋無力症に対する術式として報告されている剣 状突起下アプローチによる胸骨吊り上げ胸腔鏡下摘出 術2,3) を施行した。胸腺腫や重症筋無力症の際には横 隔神経の確認と頝部胸腺周囲脂肪織の安全かつ確実な 郭清を目的に, 肋間からのアプローチや頚部切開が併 用されることがあるが，本症例においては囊胞の摘出 に際して必ずしも横隔神経の確認や䅡部操作の必要性 はないと判断し剣状突起下アプローチのみとした。ま た胸腔鏡には硬性のものではなく, フレキシブルス コープを用いた。操作上に大きな問題を生じることな く完全切除が可能であった。術後疼痛，ドレーン留置 期間や入院日数，美容などにおいても優れた結果を得 ることが出来た。前縦隔腫瘍に対する胸腔鏡下摘出術 のうち剣状突起下アプローチによる方法と肋間からの アプローチによる方法の比較は今後, 詳細に検討され るべき課題と思われる。しかし胸骨正中切開に近い視 野が得られること, フレキシブルスコープを用いれば 腫瘍の頭側面も含めて周囲を十分観察できること, 血 管損傷などの不測の事態が生じた時は体位変換を要せ ずそのまま胸骨正中切開に移行できること, 胸腔内の 癒着の有無は問題とならないこと, 術中片肺換気を要 しないこと，ポートなどによる肋間神経損傷の心配が なく術後疼痛が極めて軽いこと等は肋間からのアプ ローチでは得ることのできない本法の利点と思われる。 胸腺腫や重症筋無力症のみならず前中縦隔の囊腫性病 変を含む良性腫瘍に対しても本法は有効な方法である と思われる。

\section{結語}

剣状突起下アプローチによる胸骨吊り上げ胸腔鏡下 手術により摘出しえた胸腺囊胞の 1 例を経験したので 報告した。

\section{文献}

1) Iwasaki A, Hiratsuka M, Kawahara K, et al: New technique for the cystic mediastinal tumor by video-assisted thoracoscopy: Ann Thorac Surg 72: 632-633, 2001.

2) Hsu CP: Infrasternal approach for thoracoscopic thymectomy: Surg Endosc 16: 1105, 2002.

3) Akamine S, Takahashi T, Oka T, et al: Thymic cystectomy through subxyphoid by video-assisted thoracic surgery. Ann Thorac Surg 68: 2339-2341, 1999. 


\title{
A case of thymic cyst resected by thoracoscopic technique through the subxiphoid approach with sternum lifting
}

\author{
Takatoyo Kambayashi, Nobuhiro Ono, Yasuji Terada
}

Department of Thoracic Surgery, Nagahama City Hospital, Japan

\begin{abstract}
Benign mediastinal tumor is usually resected with thoracotomy or VATS by an intercostal approach. We resected a thymic cyst by a subxiphoid approach with a flexible thoracoscope. An 80-year-old man was referred to our department for evaluation of dry cough. Chest CT and MRI revealed a rounded cystic mass $44 \times 42 \times 38 \mathrm{~mm}$ in diameter with a clear margin, located at the left side of the anterior mediastinum. It was removed successfully by thoracoscopic technique through the subxiphoid approach with sternum lifting. Histopathologic examination revealed the diagnosis of a thymic cyst. We conclude that this approach is effective for the resection of benign tumors located at the anterior mediastinum.
\end{abstract}

